Wilfrid Laurier University

Scholars Commons @ Laurier

3-13-2009

\title{
Club Talk: Gossip, Masculinity and Oral Communities in Late Nineteenth-Century London
}

Amy Milne-Smith

Wilfrid Laurier University, amilnesmith@wlu.ca

Follow this and additional works at: https://scholars.wlu.ca/hist_faculty

Part of the History Commons

\section{Recommended Citation}

Amy Milne-Smith, 'Club Talk: Gossip, Masculinity and Oral Communities in Late Nineteenth-Century London' Gender \& History, Vol.21 No.1 April 2009, pp. 86-106. DOI: 10.1111/j.1468-0424.2009.01536.x

This Article is brought to you for free and open access by the History at Scholars Commons @ Laurier. It has been accepted for inclusion in History Faculty Publications by an authorized administrator of Scholars Commons @ Laurier. For more information, please contact scholarscommons@wlu.ca. 
Amy Milne-Smith

"Club Talk: Gossip, Masculinity and Oral Communities in Late Nineteenth-Century London" Gender \& History,

As a small group of men gather in their favourite London club at the end of the nineteenth century, they see a familiar face and call him over:

'Hullo Beauchamp! Put down that paper and join us.' 'So I will, my boy-so I will.' ... 'Any news to-night?' 'Oh, there's the usual amount of politics; and these $\mathrm{d}-\mathrm{d}$ agitators have got up another strike! But I saw one thing in the papers that pleased me not a little; Walters has become second in command of the 200th, so I suppose he is safe to get the regiment in another four years. He has deserved his promotion well, and will be as smart a colonel as ever sat in a saddle.' 'Ah! Walters? Wasn't he a ranker? And haven't I heard that he did very well in South Africa, and got the VC there?' 'He got a great deal more than the VC and his commission put together. He got the nicest wife in the world. Oh, man! I nearly fell in love with her myself once, but she would not look at me.' 'Well, that's not surprising, - not that she would not look at you, of course, but that you nearly fell in love with her. You always had a susceptible heart for anything that wore a petticoat. Tell us all about it, and how Walters cut you out.' ${ }^{1}$

Brigade-Surgeon Beauchamp is called away from the solitary enjoyment of his newspaper to join in more convivial pastimes. He was likely asked to join the group because of his reputation as a storyteller; the first thing his companions ask him about is the news. As he sorts through his store of knowledge, he brings up and discards political and social events in order to relate personal details of an absent friend. Giving his companions a hint of the story, he is then asked to recount the entire tale and starts off an evening of pleasant gossip and conversation.

At first glance, such a scene is unremarkable; a group of men gather to share a story in a gentlemen's club. And yet the tale is not primarily about the narrator's experiences. Instead it is the story of the humorous adventures and misadventures of a man who is at least a vague acquaintance of all those gathered. Beauchamp is demonstrating his personal knowledge of individual people doing interesting things, and is able to weave it into an amusing tale; he is gossiping. And this fictional tale is related in the pages of a popular men's magazine named after a London street lined with the most exclusive social clubs in the city: in essence, doubly situating the story within the heart of the elite male world. Despite scattered critiques, elite men's gossip was commonly presented as a diversion neither to condemn nor reform.

This article presents a thick description of the rituals of privileged talk, investigating how gossip was largely accepted as a normal activity for elite men. It traces the lived experiences of men of the upper classes and places them within their world: the gentlemen's clubs, renowned centres of men's talk. In sharing gossip within the clubs, members created and reaffirmed social and gender boundaries. By telling stories, clubmen helped solidify the identity of the elite London man, both within their own community and in society at large. Gossip demonstrated you had access to certain information, stories and jokes that set you apart from women and the rising middle classes. ${ }^{2}$ When and where you told those stories evidenced your knowledge of particular modes of gentlemanly behaviour and discretion. Men's club talk provides a particularly illuminative example of how gendered and class identities were intimately connected.

Any story of clubmen's talk will first have to contend with the larger understanding of gossip in recent historiography. Thus framed, this article will investigate the particular kinds of 
gossip circulated in the gentlemen's clubs, and how gossip helped cement class and gender ties through these institutions. Turning to the unwritten rules of gossip, the article will look at the contested definitions of when and how one betrayed information gathered at the club, and how this reaffirmed male codes of honour. Finally, I will turn to the role of society journalism in both the spread of gossip and the challenge to clubland secrets.

One must begin with definitions, as the line between gossip and conversation is indeterminate. James C. Scott defines gossip as a story told about an absent party, 'an anonymous tale with no author but many retailers'. ${ }^{3}$ In many instances the desire to tell a 'ripping yarn' surpasses any larger moral or social goal such talk might have possessed. ${ }^{4}$ Gossip can also be characterised by how it often transmits information in a judgemental or malicious way. There is often a speculative nature to such talk; it is often based on rumour, and exempt from verification. While these negative definitions of gossip existed, other understandings of the term coexisted with them. One final definition of the term gossip was exempt from the common negative overtones, referring simply to conversation about people or events that was free from constraint. ${ }^{5}$ While gossip could be used to instigate personal attacks, it was just as likely to centre on trivial and inoffensive stories. Much of the pleasure of gossip derives from the belief that one is gaining personal information about a person or subject not known by the public at large; gossip in this way can bind people together in a network of shared information. ${ }^{6}$ Various types of talk help demonstrate how one person's gossip is another's conversation.

The historiography of gossip is flourishing, yet it has overlooked the nineteenth century English gentleman. ${ }^{7}$ James C. Scott portrays gossip as one of the few means by which peasants could express discontent while hiding behind the appearance of submission to authority. ${ }^{8}$ Bernard Capp looks at female gossip networks in the early modern era, examining how they harnessed the power of gossip to negotiate male domination over their society and how men critiqued them because they recognised its subversive power. Capp also points out that gossip networks were 'at once supportive and divisive, creating boundaries ... based on exclusion as well as inclusion'. 9 John C Beard Haviland takes this analysis further in his investigation of the Zinacantan, pointing out how gossip is a means by which members of a society demonstrate, question and shift the cultural rules of that society. 10 What these diverse scholars share is a tendency to see gossip as a tool whereby those outside of the sites of power subvert, manipulate and engage with the dominant society. Gossip is thus largely understood as a tool of the marginalised.

However, gossip has a function beyond the excluded classes, and was very important amongst the elites. Laura Gowing points out that gossip, scolding and the language of scandal is a broader social power that is shaped and constructed depending on who is telling the tale. ${ }^{11}$ In the case of the upper classes, Scott tells us historians should look for stories told behind closed doors; when the masks that the powerful adopt in the presence of subordinates are dropped, we discover new truths about the dominant group. ${ }^{12}$ While rich white men have arguably been the focus of historical research since its inception, it is often only their most public lives that are examined. There is a significant lacuna in understandings of how such groups of men interacted in private social situations. It is in exploring the privileged dynamics of the ruling elites that gender and class distinctions are revealed in some of the most meaningful ways. Particularities of status and masculinity were minutely worked out in the society of clubmen as they fought to exclude women and monitor the actions of men.

Anthropologists have long noted that gossip is frequently used as a mechanism of social control. Members of society demonstrate their knowledge of their own community both by their ability to understand gossip and to participate in its creation. ${ }^{13}$ Clubmen needed to know how to 
tell a story to their best advantage, balancing the line between boasting and self-effacement. They also had to know when not to tell a story, and demonstrate the reticence of a true gentleman. Elite men needed and used the power of exclusionary gossip to monitor behaviour and at the same time, to reinforce the sense of 'insider' status. ${ }^{14}$ Clubmen's gossip was about proving one's masculinity, but a particular kind of masculinity, that of the gentleman.

Newcomers had to work very hard to break into this world and learn the unwritten rules, and they did not always succeed.

The gentlemen's clubs of London demonstrate key sites of male gossip; they were distinctly homosocial spaces where talk was a leading attraction, and could lead to practical results in the outside world. The informal rules surrounding what were acceptable and what unacceptable topics and manners of talk highlight an important facet of the larger gentlemanly ideal. ${ }^{15}$ Following a set of rules of privacy and secrecy, clubmen regulated and controlled their gossip and thereby transformed an often-feminised form of communication into an acceptable part of the male identity. Good storytellers were lionised and some evenings of seemingly innocuous gossip often had a subtext of hyper-masculine contests of wit and knowledge. Club gossip served to help construct a community of shared private stories whose tellers demonstrated their grasp on the unspoken rules of subtlety, humour and good taste. The boundaries of secrecy were tested by the rise of the celebrity press whose desire to share stories threatened the 'clubland' community whose particular allure lay in its exclusivity. A successful gossip had to navigate this complicated terrain in order to carve out a solid place among his peers.

Talk was integral to the success of gentlemen's clubs, and had been essential to club life since its origins in seventeenth-century coffee houses. Indeed, the phrase 'coffee house tale' signalled a particular type of storytelling among men that was a heavy mixture of falsity and frivolity. ${ }^{16}$ The old coffee and chocolate houses of seventeenth-century London epitomise the democratic public sphere and a society where men of varied social backgrounds shared their ideas; as clubs evolved in these spaces, the oral culture continued but the democratic impulse was curtailed. ${ }^{17}$ By the late nineteenth century, the gentlemen's clubs of London had become centres of socialisation for some of the most wealthy and powerful men in Britain, and reached the peak of their popularity. Even with over one hundred clubs in the metropolis, prospective members could wait decades to come up for ballot at the most sought-after institutions. ${ }^{18}$ The luxurious male-only clubhouses provided a place to dine, to meet with old friends and to enjoy a moment of quiet in the middle of the busy metropolis. As such, these social clubs created a homosocial space for the British elite that proved ideal sites for gossip.

Gathering in the smoking room to discuss the latest news of the day was a typical scene in any clubhouse. When clubs closed, it was as a source of the latest social news that many members missed them the most. ${ }^{19}$ For some clubs, their store of gossip was actually the main attraction. The New York Daily Tribune complimented the St James's Club as site of the best gossip in London. ${ }^{20}$ As the foremost club of diplomats and foreign dignitaries, the St James's could boast the top stories from around the world. The hall of the Athenaeum Club was another premier place for the latest gossip as well as information from the news agencies. People gathered there to talk, and it was often one of the busiest spots in the club. ${ }^{21}$ Clubmen recognised that only rarely did men discuss matters of the greatest importance in their clubs. Instead, one author pointed to the basic triviality of club talk, and how most conversation came from 'bores and billiard-players'. ${ }^{22}$ This inherent frivolity did not, however, limit the importance of talk, nor did the use of the word gossip. 
In the face of such evidence of men's gossip, the deep assumptions of gossip as a female trait must be explained. The origins of the term 'gossip' find a deeply feminised history that is echoed in popular understanding today; this helps to explain the persistent associations of women and gossip. Gossip was originally gender neutral, a term for a godparent, first identified as a sponsor for a baptism in the eleventh century. However, gossip quickly became feminised and lost its original meaning. The term became associated with female friends in the midfourteenth century, although it was often still tied to those present at a birth. Women also referred to close female friends as their gossips, with whom they would chat and exchange information. ${ }^{23}$ It was not until the sixteenth century that gossip became a distinctly critical term to describe a woman who enjoyed idle talk and the latest news. ${ }^{24}$ The negative characterisation of gossip largely stemmed from men's fear of women's talk; not only were gossip networks potentially subversive, the possibility that women could discuss details of men's sexuality was threatening and emasculating. ${ }^{25}$ This definition of gossip remained fairly constant, as was its association with women. And yet, despite persistent attempts to feminise and dismiss gossip, it remained a dominant part in women's and men's lives of every class. And in the nineteenth century, coexisting with the feminised critique of gossip, was a normative understanding that men gossiped as well.

In the nineteenth century, some stereotypes about gossip being a particularly female failing persisted. Women were not only believed to talk more than men, their conversation was typically portrayed as more frivolous than their male counterparts. Punch and other satirical works liked to point to women as the premier source of salacious news. In one cartoon, a man poses to his female companion a question as to the three fastest methods of communicating. She quickly thinks of the telephone and telegraph, but cannot think of the third. He knowingly responds, 'Tell a Woman!' ${ }^{26}$ Such witticisms were so common they became cliche. Within the framework of the ' cartoon, the woman is granted no reply, nor any reaction. And yet this was only ever one half of a larger discourse. Punch recognised men's proclivity to gossip just as readily: under the title 'The Joys of Scandal-Bearing' it is a group of well-dressed men, and not women, who are gathered on a street corner to learn all of the lurid details of a recent scandal. ${ }^{27}$ There is substantial evidence that suggests that Victorians were well aware that gossip was a universal pastime, especially among men who did not have much else to keep them busy.

Male gossip was still occasionally criticised as a feminised aberrant from the norm of male reticence, but the weight of evidence countering this type proves otherwise. In fact, it is the everyday, unconscious connections between men and gossip that best demonstrate the popular recognition of male gossip. The elitist social paper the Court Circular, for example, had a weekly column in the 1880s entitled 'Club and Social Gossip' written by a man-about-town. When the New York Times reported on English gossip, men's lives and men's talk were often the focus of the attention. ${ }^{28}$ Such columns spoke to a male and female audience about leading Society events and personalities, and were often written by male authors. ${ }^{29}$

Even when the topics under discussion were distinctly imagined as exclusively male, gossip was still used as the descriptive term. In 1904 and 1905 the Pall Mall Magazine regularly had sports columns headed 'Rifle Range Gossip', 'Gossip from the Links' and, under racing news, 'Headquarters' Gossip'. While some of this information was simply statistical or provided tips that other men could emulate, often it contained rumours and speculation. In particular, the world of the turf was rife with gossip and innuendo heightened by the large sums of money bet on the horses. ${ }^{30}$ Horse racing and hunting might have been imagined as distinctly male worlds, yet men gossiped about them as avidly as the latest fashion. Not only did men actively engage in 
such discussions, in the gentlemen's clubs of London it was a major pastime. Men accused women of being gossipy, and self-consciously created a world governed by rules that supposedly made what they did different. Thus male gossip is self-consciously masculine, and it is not surprising that it often dwells on political issues; when it does address social issues, the lessons are often explicitly about how to be more of a man.

Trying to unravel club gossip in the historical record is an intrinsically difficult project; gossip was primarily talk and thus not readily recorded. The actual evidence in the written record is somewhat thin, and incredibly scattered. However, club gossip has been passed down in a variety of ways. The famous betting books of White's, Brooks's and Boodle's clubs give some indication of men's predictions and opinions as members recorded their friendly disagreements in the form of wagers. The subject of bets varied little at White's from the eighteenth to the nineteenth century and focused mainly on wars, foreign affairs, cabinet appointments, court cases, divorce scandals and internal club politics. ${ }^{31}$ Betting books went in and out of fashion at the various clubs, yet they remained a most treasured institution. ${ }^{32}$ The betting books were placed on display for all members to view, and thus acted as a semi-official receptacle of gossip. Similarly, published and unpublished memoirs record club stories of political, business and court intrigue. The most prominent topics of club gossip broke into public scandals when they became too fantastic to be contained and thus find traces in the periodical press. As for the day-to-day conversations between men, short stories and works of fiction give some sense of what members talked about and certainly give a sense of what people thought was being said in the inner sanctums of the clubs. And the clubs themselves offer limited accounts of what happened when unruly gossip led to formal reprimands for the breach of club etiquette. While the actual conversations will remain a mystery, what can be gleaned is that gossip could range in character from the harmless to the deeply personal.

The most obvious recorded instances of gossip surround political life. Fleeting references to political gossip are a common feature of men's memoirs whose authors expound at length on the political news of the day. ${ }^{33}$ This is in keeping with the general tone of such works; these public men placed far more emphasis on their public lives than their private. It is likely that political gossip was a common kind of talk within the clubs themselves; gentlemen took pride in their knowledge of, and stake in, the future of the nation. Edward Hamilton was perhaps the closest Victorian equivalent to the so-called professional gossips of the eighteenth century, such as Horace Walpole, who collected information and innuendo. Hamilton's fifty-four-volume diary details twenty-six years of political and social life in London. A consummate clubman, his journal gives a rare sustained insight into the interiority of club life. As a private secretary to Prime Minister William Gladstone and later in the Treasury, it is unsurprising to find that much of his conversation was political. Hamilton was a political insider and, while he discusses concrete matters of policy, his entries were also often marked by rumour and speculation.

One evening at the Bachelor's Club, Hamilton found himself among a group of political heavyweights for dinner. Among their discussion topics, he records that the critique of a prominent leader was the most memorable, and enjoyable.

Had a pleasant dinner with Guy Dawnay at the Bachelors Club. His brother Lewis (almost as nice as himself) Lewisham \& Mosby [?] formed our party. One can never dine in Tory company (and one comes across a great deal of such company) without hearing Sir S. Northcote slighted. ${ }^{34}$

Political conversations were laced with gossipy predictions and speculations. Dining at Brooks's Club with another political insider, Hamilton found his companion quite 'freely' discussed his 
pessimistic opinion of contemporary political life. ${ }^{35}$ It is the unrestrained nature of the talk and the retelling of rumours that characterised the conversation as gossip. Hamilton does not attempt to justify or defend these conversations about second-hand information; political gossip is naturalised as a neutral form of conversation.

Recording gossip and conversations in not only private but even published memoirs was common. Politician and clubman Montstuart Grant Duff enjoyed a wide range of conversation with friends at various clubs throughout London, and he recorded some of these stories in his published diary. Political gossip also formed a part of his conversation and was not limited to affairs in Britain. In February 1896 he found himself talking about literature and French politics at his breakfast club, and in January 1898 he talked Romanian politics at the St James's with a group of men that included an ex-minister of that country. ${ }^{36}$ Duff was light on details, but he certainly saw nothing controversial in his actions. Henry Lucy was a journalist by trade, and thus it should come as no surprise to see his memoirs filled with the latest news. He also records topical gossip, including rumours surrounding memberships in political clubs. For example, Lucy wrote that 'the fat is in the fire at the Reform Club' when friction between Liberals and Liberal Unionists broke out there in 1900. Lucy recalled how devastating the original break over Home Rule for Ireland had been to the Reform and wondered if history would repeat itself. ${ }^{37}$ Lucy recorded such musings in his diary as examples of the shared gossip among political insiders of the day. And while an impressive evening of political gossip could sometimes lead to real advancement and opportunities, some words could have devastating consequences.

Politics often played a major role in club blackballing, and was a constant source of gossip and speculation. The use of the blackball to declare that a prospective candidate was not worthy of membership in one's society was particularly powerful. The Travellers Club had a reputation for the free use of the blackball, and was known to have rejected candidates based on partisan politics despite the club's non-political nature. ${ }^{38}$ Brooks's Club showed the legacy of its eighteenth-century Whig history when internal party politics nearly ripped the club apart in the 1880s. After a hotly contested by-election, the Chancellor of the Exchequer made an offhand, but disparaging remark about dissident members of his own Liberal party in the club dining room. Rumours soon spread among the members leading to a spate of blackballings in retribution. ${ }^{39}$ The circulation of political stories and gossip in this case almost spun out of control.

While politics was certainly a popular topic at the clubs, it was not the only thing men talked about. Political gossip is the easiest to trace in printed memoirs, as it was part of many men's professional lives and almost always the focus of such works. In the popular imagination, however, it was women who were the primary focus of attention in clubland. One is more likely to find club-talk dominated by discussions of women over politics in popular or anonymous stories, as few men were willing to admit such things in their personal memoirs and many would not have considered such events noteworthy enough to record. ${ }^{40}$ While finding confirmation of women's place in clubmen's conversation is difficult to trace in actual memoirs, there are enough hints to indicate that women probably were a hot topic of conversation. To gossip publicly about a woman would have been considered an affront to the lady's honour and the surest way to destroy one's own. Yet the club was hardly public, and to gossip behind closed doors was inevitable. These conversations remained acceptable by staying within the clubhouse. When they are published, it is often years after the event so as not to offend. ${ }^{41}$ However, in fictionalised stories, authors could be more indiscreet.

Some tales were humorous, others had more overt moral overtones, yet the policing of heterosexual identities was a common denominator. In one story, a group of men gossip about a 
young woman who had taken up bicycling and the wearing of knickerbockers, only to have their mocking overheard by her prospective fiance. ${ }^{42}$ The woman's actions were classic symbols of the 'New Woman', icon of feminist ideas and a marker that the gender order was upside down. Any cuckolding of the husband in this story is only subtly implied. At other times, the gossip was more lascivious. In one story a man is taken aside by a friend at his club and warned that his stunning wife had frequently been seen in the company of a man with a very bad reputation. The warning came too late however; the woman had already run away ${ }^{43}$ The fault was presented as the man's for failing to notice a problem, to control his wife and avert the issue. Both stories were about men whose women were somewhat out of control and, while the latter was far more serious, both implied a weakness of the man involved that the clubmen were trying to counteract.

One reason gossip was acceptable among clubmen, and did not often receive the censure of women's idle talk, was the very fact that there were rules governing its practice (at least in theory). One of the key features of acceptable gossip was that it demonstrated the wit and knowledge of the speaker. The ability to share a good bit of gossip, and to tell a humorous yet inoffensive story, was linked to a gentlemanly ideal that required men to prove their wit on the battleground of public opinion. As emporia of gossip, the clubs served as spaces to cement a man's reputation for cleverness. White's Club, for example, was distinguished as one of the most exclusive and elite clubs by its high level of conversation. Its members proved their quality by their well-crafted talk, whether it was of sports, politics or the latest divorce scandal ${ }^{44}$ Such words could range from benign commentary to refined insults. In giving advice to a young man seeking entrance to his first club, one author felt that to develop one's gossiping skills was a priority:

You are about to join a Club to sharpen your wits, since in every Club worthy the name every man practises his tongue in the elegances of neighbourly abuse, and is not considered anything of a fellow if he cannot command rasping repartee or some pretence to bon mots. ${ }^{45}$

Such verbal training was necessary for a new member of the upper classes in particular. Being able to tell a good tale was an important way of demonstrating membership in the society of clubland, and one's status as a gentleman.

To be a member of a gentlemen's club was to be 'clubbable', an essentially self-reflexive word. ${ }^{46}$ To be a good member of a club meant to be clubbable, and to be clubbable was to be a good club member. The ideal clubman was not the middle-class ideal of the respectable 'City' man who did his job, went to church and paid his taxes. In many ways the clubman was the antithesis of the City man: secure enough of his status, he was allowed and expected to have a few vices as long as they were not 'vulgar' ${ }^{47}$ The perfect clubman came from a good family, knew enough about the world to be good company and was enough of a man of leisure to while away an afternoon at his favourite club with a good glass of brandy. And the ability to be able to both tell and listen to a good tale was paramount to such an afternoon. The type of story told was supposed to be gossipy if not fictional in nature. In E. F. Benson's anecdotal description of his younger years, one man is described as being 'remarkable for his reputation of being the greatest liar in India' ${ }^{48}$ Far from being a critique, he thought 'to have such a reputation is endearing; it connotes a garrulous and clubbable fellow' ${ }^{49}$ To live a life with enough embellishments to be interesting without being scandalous was the sine qua non of the clubman.

Stories of men's abilities to recognise and preserve the boundaries inherent in the gentlemanly ideal were also reinforced through gossip. The story of a young man who killed himself over his inability to repay a card debt was the centre of a particularly juicy gossip circle 
in one fictional Vanity Fair story. Although the events happened in India, it is in a London club that a friend of the deceased man overhears the story. The young man who committed suicide was unable to repay debts of honour, a distinctly unmanly act; to borrow money appeared cowardly to him and therefore the choice to end his life perhaps seemed the only way to escape his shame. The clubman had been unable to convince his friend to take a loan to cover his debts, but he was more successful in ending the club gossip. He interrupts the men and retells the story in a way that makes his friend appear the wronged party. ${ }^{50}$ The clubman takes on the task of rehabilitating the deceased man's reputation, and his manly honour, as a tribute to their friendship. The clubman thereby seems all the more honourable to the reader, for he is willing to undermine his own character in an attempt to help his deceased friend. The story does not critique gossip per se, but instead correctly outlines how men are supposed to retell stories and maintain their honour. ${ }^{51}$ Gossip used correctly is thus a vehicle through which a man can demonstrate his nobility and the ability to put another's reputation above his own. It also outlines the boundaries of how a gentleman and clubman is supposed to behave.

Bending the truth of a story did not necessarily reflect badly on the teller if there was a noble intent, or even simply the desire to entertain; some of the best stories made little claim to accuracy. The notion of a 'club yarn' implied an entertaining tale with only a light grounding in reality. In 1894 the Pall Mall Magazine published a series of short stories under the heading 'Yarns in the Club Smoking-Room', and Vanity Fair had its own series of 'yarns' centred in a club where men recounted their best tales of politics gone wrong. ${ }^{52}$ One could certainly overhear a wealth of gossip at a club, but the veracity of the facts and the quality of the opinions could be called into question. The club smoking room became synonymous with such narratives. ${ }^{53}$ In 'Overheard at the Club', while three young bachelors wait for their meal to arrive, they recount rumours of the Labour Party's plans to invade the West End and take over their country seats. The three work themselves up into a panic before the sensible fourth arrives and tells them that politics are silly and the important thing is to have lunch. ${ }^{54}$ Club talk could garnish useful information, but it could equally impart baseless facts and opinions. Fictional stories in particular seemed crafted to impart stories where clubmen learn important lessons through gossip, if not necessarily factual information. ${ }^{55}$

Men could gossip without threatening their masculine identity if they obeyed the rules of discretion and propriety; it was the common acceptance of such rules that helped bind clubmen together. The worst kind of gossip was built on lies and motivated by the desire to hurt or injure someone. Men could also demonstrate their own nobility by not gossiping about those who could not defend themselves and by knowing how to tell a tale to good purpose.

Although gossip finds no official mention in any rulebook, the unwritten rule of privileged speech was foundational to club life. ${ }^{56}$ The chronicler of Boodle's Club notes that 'Part of the charm of English Club-life - and one of its most honourable traditions - is that, while it provides a refuge from the hubbub outside, what may happen inside is not retailed to the man in the street - not even to the man in that street whose business is news'. ${ }^{7}$ The author then goes on to point out that this reticence is the reason why no records of any particularly scandalous moment from Boodle's Club survive if such events occurred. ${ }^{58}$ While clubs may have been the best centres of gossip, the information gathered therein was considered sacred and members knew they were not to repeat it elsewhere.

Noting the absolute secrecy demanded by individual clubs was a common conceit in club histories. An article for Harper's Magazine points to the Beefsteak Club as one of Henry Irving's favourite entertainment centres yet cites the secrecy of club life as a reason for providing no 
further details. ${ }^{59}$ The secrecy demanded by club tradition allowed men to feel at ease in the knowledge that stories shared within club walls would not become public knowledge. In writing his history of the Savile Club, G. M. Wrong celebrated that the Club was 'a place where you can say what you please within rather wider limits than usual'. ${ }^{60}$ It was this manly restraint, of knowing when to share a tale and when to keep silent, that marked club gossip as acceptable. The attempts to regulate and justify men's gossip can be seen as an attempt to masculinise what could be an irrational, specious and emotional form of talk.

Club secrets were sacred for a number of other reasons. For public men with juicy secrets, the idea of having a privileged space of free speech was invaluable. The exclusive clubland community, chosen by a rigorous election process and guaranteed by club laws, both official and unofficial, guaranteed a commonality of interest. Clubmen were bound together by their secrets, which helped define their community. Gossip networks could thus help cement the boundaries of the community by separating itself by a shared pool of knowledge. ${ }^{61}$ This added a sense of mystique to the stories told there and reinforced the idea that the best stories were reserved to the smoking rooms of the most exclusive clubs. ${ }^{62}$ Much like, and working in tandem with, the old boy network created by public schools, the military and the universities, clubs helped form a London-based society which shared a pool of knowledge and a code of ethics as to how to protect that knowledge. ${ }^{63}$ Even if a man found a room full of strangers in his club, he could rest assured that they would all act with discretion. For men who lived so much of their lives in the public world, the ability to carve out a more private space for themselves was invaluable.

The promise of privacy made men freer with their talk and made conversations lively. One author frankly admitted a gossip was a welcome member of any club: 'The gossip is not merely an endurable creature. He is an essential factor in our social existence'. A man became unacceptable only when he gathered information at his club and then spread the tales into general society; a club gossip's information was supposed to travel in the opposite direction. ${ }^{64}$ It was part of the gentlemanly ideal not to seek out gossip or lurid stories, but he could share any stories that he happened to come across in his interesting and varied life. A true man and gentleman would know how to tell a good tale, and where and when to share such information.

While specific details of club life were privileged information not for the public eye, they were not secret societies and did not shun publicity entirely. Clubs were proud of their institutions and their traditions and wanted the public to know about them in a general sense. Reporters commonly wrote overviews of London clubs, although they were formal, institutional histories and did not contain details of topical events or scandals. ${ }^{65}$ When the Art Journal compiled its overview of club life in London in 1885, the author explicitly rejected the idea of publishing any personal information about clubmen of the present day. He cited 'the friendly confidence of the club-house' as the reason that his reportage would reveal no club secrets.66 Club committees and members were not averse to published accounts as long as they betrayed no specific details.

Clubs were rigorous in their attempts to control published information. Percy Fitzgerald was finishing a history of the Garrick when he received a letter from the Club committee asking to see the proofs. The committee feared the text would reveal private information about club life not meant for public consumption. Fitzgerald responded with outrage, stating that no events of the past forty or fifty years were even mentioned. ${ }^{67}$ He was a member of the club and knew the rules of discretion and good taste. The committee was so concerned with its own reputation, however, they sent another letter to Fitzgerald that made 'certain insinuations as to the doubtful 
methods I was about to employ'. ${ }^{68}$ The committee's paranoia proves how important it was to maintain the privacy of the club walls. Fitzgerald's indignation points to how a man's honour was tied into his knowledge of the rules of clubland.

Transgressions of the unwritten laws of secrecy were seriously policed. House of Lords records contain the copy of a confidential letter about a political scandal at the Carlton Club. The details of the event are somewhat veiled but can be summed up by the fact that 'a member of the club had repeated to a political opponent in high official position certain statements made by a brother member of the club ... in the club itself'. ${ }^{69}$ Essentially, a member listened in on some club gossip and then repeated that gossip to a political opponent. The political nature of the offence only highlighted the original transgression of repeating privileged information. The letter indicates that the events are leading to a crisis and they call on Andrew Bonar Law, then leader of the Conservative Party, to help discern any attribution of guilt. The point was to avoid a formal disciplinary meeting of the Carlton Club committee whereby the offending member could be expelled and further publicise the event. ${ }^{70}$ Whether this occurred is not recorded, but the transgression of repeating gossip in the wrong place was clearly a serious offence.

Betraying a member's privacy to the detriment of his public life and character was against all codes of fraternal respect embodied in the principle of club membership. While politics was an important part of many men's lives, personal political squabbling and petty party animosity were supposed to be left beyond the clubhouse doors. The fact that concerned parties attempted to settle the dispute outside the committee room implied a desire both to avoid punishments being handed down and to limit the spread of the story. ${ }^{71}$ Although still contained within the club, even appearing before a committee rendered gossip more public, and thus more serious, than it need have been.

The code of club secrecy followed in tandem with a more general withdrawal of the upper classes from public society. Elite men and women withdrew from socially promiscuous entertainments throughout the nineteenth century as a reaction against middle-class challenges to their social dominance. ${ }^{72}$ Behind the impressive facades of the gentlemen's clubs, the men at the top of the social ladder could display their exclusivity without revealing details of the proceedings within. Outsiders knew that secrets and stories were shared behind closed doors but could not gain access to the details. Clubmen gloried in their privileged knowledge as much for what it represented as for the actual news itself.

Clubmen wanted the world to know they had secrets to keep. Such a community based on common knowledge was reinforced in veiled references to famous people and events both in public and private. Hints and fragments of personal gossip often entered the public domain by way of newspapers and magazines largely devoted to the purpose. These publications helped add to the mystique of Society, and club 'yarns' suggest that, in the absence of insider gossip, such stories had to be invented. Stories would sometimes be retold with names omitted, allowing only those who knew the particulars and personalities to understand the references. Thus within a more public setting, enough information was given so that only those who knew the characters involved would get the joke, and those outside the privileged circle would remain in the dark. ${ }^{73}$ Jokes typically grant an insider's view of social structure, as they depend on a consensus of knowledge for recognising the humour. ${ }^{74}$ Even if the information gathered within clubhouse walls was mundane, it was the privileged nature of that information and the ability to unravel coded meaning that made it so important. Thus club gossip was important for its part in distinguishing an upper-class community joined by secret stories and privileged information. 
The exact definition of when one crossed the line of repeating club secrets was contentious and contested. One of the most famous literary fallings-out of the nineteenth century was caused by the supposed publication of club secrets. Edmund Yates was a young member of the Garrick Club and a friend of Charles Dickens. He wrote a gossipy column for the Illustrated Times entitled 'The Lounger at the Clubs', wherein he often praised Dickens. ${ }^{75}$ One week, however, Yates used his column to write a rather unflattering portrait of another prominent novelist, William Thackeray. Thackeray was incensed. He felt that the only way Yates knew him was through the Garrick, and thus Yates must have drawn his information from that source: 'We meet at a Club, where, before you were born I believe, I and other gentlemen have been in the habit of talking without any idea that our conversation would supply paragraphs for professional vendors of "Literary Talk"" ${ }^{76}$ Thackeray was furious that his character was being assessed and his private life studied for publication in a place he thought was free from public scrutiny. ${ }^{77}$ The secretary of the Garrick agreed and wrote to Yates admonishing him that his article was 'fatal to the comfort of the Club, and is intolerable in a Society of Gentlemen' ${ }^{78}$ From the committee's point of view, if members felt they were constantly under the glare of the journalist's critique, they could not really feel at home in their clubs.

Yates disagreed with the decision, however, and felt his caricature of Thackeray betrayed no reference to the club or any specific information gathered therein. When the committee began action to expel Yates, his lawyers protested. ${ }^{79}$ Yates himself had no fear of making the scandal even more public as he published copies of the entire correspondence between himself, Thackeray and the Garrick. ${ }^{80}$ As Yates was a protege' of Dickens, the author sided with the young man and the two abandoned the Garrick for the Arts Club; Dickens and Thackeray did not speak again for fifteen years. ${ }^{81}$ Dickens, Yates and Thackeray clearly had different definitions as to what degree the Club was a privileged space, and it was enough to break up a friendship.

The case of Yates and Thackeray merely highlights the faith people had in the privacy of their club lives, and the feelings of betrayal when they felt that privacy had been breached. At their core, such disputes demonstrate the role of gossip in solidifying the club community. Because clubmen shared facts and stories, and upheld a tradition to keep that information privileged, they became a sort of fraternity of secrets. Knowing what stories should be told, and when, was a marker of a clubman's identity.

To tell certain club tales was bad form, but to openly publish that information in a newspaper or book was considered a betrayal. The explosion of society journalism in the nineteenth century made the issue of publicity prominent and took the idea of a professional gossip to another level. While the medium was typically recognised as a harmless innovation, 'Society' papers did more than simply print existent gossip as part of journalism: the new medium bred the desire to know the private details of public personalities. By speculating on the fortunes and futures of the great and the good, they also created new forms of gossip. ${ }^{82}$

By the late nineteenth century, journalists of all sorts were trying to be more representative and thus included more domestic and female-friendly issues and topics. ${ }^{83}$ Nonetheless, Society journals catering to a male audience wanted to maintain the illusion of a clear and distinct gender order, in light of the spectre of the 'New Woman', and were very sensitive about their precarious position. ${ }^{84}$ News in such publications was always a combination of public and political issues along with more novel items of gossip and celebrity news.

In response to challenges that society journalism was too intrusive, Vanity Fair, itself not immune from publishing scandalous titbits, defended the medium. The editor argued that the biggest critics of the press were addicted to the juiciest gossip. In reporting on the social life of 
the elites, he continued, society journalism varied little from the mainstream press. In fact, the 'serious' media could actually be more damaging:

The 'Society' journals are often very dreadful in their inanity and tasteless vulgarity, but the solemn journals are far worse ... The plain fact is that all men are interested in their fellow-creatures. Some of them talk about their fellow-creatures vulgarly and hurtfully; some do not. The vulgar and hurtful talk interests vulgar people. The other kind interests people who are not vulgar. This is all. ${ }^{85}$

Any charge that society journalism was spreading salacious gossip was therefore transferred onto the readership who craved such information, and not the medium itself.

Society journalism was contentious, both widely popular and widely critiqued among the wealthy and powerful. The sheer number of journals that were created, many existing for only a very short time, is remarkable proof that there was a popular acceptance of publishing details of people's personal lives. The majority of such publications focused on uncontroversial details such as what people were wearing, the newest betrothals and travel destinations of the elites. The leaders of fashionable society and Society journalists existed in tense codependence. While certain stories were meant to be kept an absolute secret, other details of many socialites' lives were open for public consumption. As a contributor for the World noted, newspapers were constantly flooded with paragraphs from hostesses detailing their latest entertainments in hopes of publication. However, if the coverage were not exactly what they expected, the paper would get wrathful letters of condemnation. ${ }^{86}$ The most vocal critics of slanderous gossip were often the very people who supplied the majority of the information.

Because of the supposed code of secrecy surrounding club life, when details of any particular club entered the public domain, it was often the cause of concern. Club elections were supposed to be rational and transparent means by which clubs chose the best members to join their society; in reality, they often spiralled into reflections of petty animosities, rivalries and grudges. The unmanly reality of cantankerous members blackballing eminently qualified candidates for no reason was therefore a sensitive subject. ${ }^{87}$ An English correspondent for the New York Times was incensed when a weekly paper publicly challenged the Garrick Club on their blackballing practices. The author feared that, with the rise of society journalists, privacy would soon become a thing of the past: "now that the newspaper market is crowded with journals that hope to live on mere personal gossip, not the smallest incident of club life or club scandal is permitted to pass out of memory without a recorder to hand it down to posterity' ${ }^{88}$ In fact, one journal attacking another for the extent of its intrusion was not uncommon. ${ }^{89}$ Despite its popularity, society journalism was in a constant struggle to justify its own existence and balance the desire to entertain with the need to maintain the illusion of a mysterious, inaccessible world of celebrity culture.

Reporters justified exposing shameful secrets to the public eye if the sins were unworthy of protection. Gossip helped define what was acceptable and what was unacceptable behaviour in society, in particular when it came to sexual morality. And when clubmen failed in their duty to use gossip as a means of social control, the press could step into the void. Such critiques could sometimes take on a distinctly gendered overtone. One female correspondent to the World magazine cheered that men too frequently in the company of unmarried girls were gossiped about, yet was outraged that men's behaviour with married women seemed exempt from comment. ${ }^{90}$ In this case, private gossip was too permissive and the female reporter had to fill in the void of policing men's sexual conduct. And this implies a critique that went far beyond this particular instance; men's gossip was not going far enough to police male behaviour. Instead, a 
woman's view, or at least a mixed-sex audience, was required to properly maintain men's activities.

Newspapers could often justify their publication of club scandals in the name of public morality. For example, Vanity Fair published a number of articles questioning the gambling practices of the St James's Club. Excessive gambling and gambling for high stakes had once been an accepted practice among gentlemen at the end of the eighteenth century. By the late nineteenth century, however, it was considered an unmanly act that demonstrated a lack of control. Consequently it was no longer a part of mainstream club life. However, a member of the St James's wrote to the magazine to protest publication of the damning article, targeting the author of the articles for publishing information that should have been kept silent. He felt 'the Club resents most justly an interference in its private affairs which nothing but a public scandal could possibly warrant'. ${ }^{91}$ Yet even in his critique of the magazine, the author admitted that some club secrets should be made public in the case of a serious enough scandal. In a rejoinder immediately following the letter, the editor defended his paper, reiterating the facts of the case. He stated that the persistent gambling problem at the St James's was grave enough to be labelled a scandal, and well known enough to be considered public knowledge. ${ }^{92}$ Elite men could not be guaranteed the right to monitor their own behaviour away from the public glare.

Men's failure to live up to the gentlemanly ideal could also be circulated by means of published gossip. A story made the rounds in the early twentieth century about an altercation at an unnamed prominent bridge club. A wealthy but unpopular member of the nouveau riche who was known to be a talkative bore lost a lot of money for his partner through bad play. The partner, who had a short temper, offered the man one hundred pounds on the day he resigned from the club. Indignant, the man charged downstairs where he met one of the club's more aristocratic members to whom he told the tale. Without missing a beat, the lord answered that of course the man should not take the money, for in a week the offer was sure to be increased to a thousand pounds. ${ }^{93}$ When published in Vanity Fair, the story included no names, but among the club initiates one can imagine men would hardly have been so discreet.

The characterisation of an aristocrat humiliating a member of the industrial bourgeoisie makes the story a cautionary tale, and the retelling of the story confirms that a 'new' man should know his place and not rock the boat. The aristocrat not only chastises the specific behaviour of complaining about a trivial slight, but manages to prove his own mastery of social situations by retelling the events in a clever way. In its published form, the decision to not include any names maintained the proper amount of discretion. This type of club story became the anecdote whereby a broader public was granted a glimpse at the gentle policing of class and masculine boundaries of club life.

Club gossip could also function as an indicator of when a scandal was too important to be kept secret. The most shocking card scandal of the nineteenth century, the Tranby Croft Affair, became a problem when the story began to circulate too prominently in club smoking rooms across London. The case centred on a house party that included the Prince of Wales among its guests. Members of the party thought they detected Sir William Gordon-Cumming, a distinguished military officer, cheating at baccarat. After an attempted cover-up and oaths of secrecy, word got out and accusations began to be openly discussed at the clubs. There was the possibility that the issue could be solved in the clubs, had the Guards Club decided to hold an investigation into the charges. However, at a special meeting held to empower the committee to conduct an inquiry, the majority of members voted to suspend their own judgement until the 
matter had been settled legally, thereby guaranteeing a full public enquiry. ${ }^{94}$ Gordon-Cumming charged his accusers with slander and the case went to trial in June 1891.

After an exciting and incredibly popular trial, Gordon-Cumming lost his case and was drummed out of society. He resigned from his clubs (the Turf, Guards, Carlton and Marlborough), lost his army commission, and retired to his estates in Scotland for the rest of his life. ${ }^{95}$ The scandal sullied not only Gordon-Cumming's personal reputation, but also those of everyone who first tried to cover up for a man they believed was a card-sharp. In this case, clubmen realised that cheating at cards was too serious to be restrained within the back corners of smoking rooms. Members sought out the story, found out its details, and decided that GordonCumming was not suitable to remain protected by their society. The values of clubland were upheld using gossip to police the boundaries and expel a member not following the rules. The communication of the details of this story were considered acceptable, as it betrayed no club secrets, acted as a cautionary tale and demonstrated that clubmen were not willing to protect ungentlemanly behaviour.

While a gentleman could, and often did, have sexual indiscretions, some things were beyond the pale. Club gossip helped regulate what happened when such secret behaviour became public knowledge. When the Marquess of Queensberry decided to destroy Oscar Wilde, the only evidence he had against him was a letter, a copy of a racy Oxford paper and club gossip. ${ }^{96}$ By handing the waiter at the Albemarle Club a card for Wilde with his accusation of sodomy written on the back, Queensberry almost guaranteed the gossip already surrounding Wilde would worsen and seep through the clubs and beyond. When gossip could not be contained to the inner sanctums of the clubhouse, it was probably because members did not believe it deserved their protection.

In the process of his social ostracism, which included selling his possessions and going to jail, Wilde also became an unacceptable member of any London club as either a member or guest. During the trial itself, talk of Wilde, his work and his actions was at a fever pitch, inside and outside the club world. While Wilde's story was widely known after the trial, it would have been indiscreet to continue to talk about a man who had already received his 'just desserts'. Just as it was appropriate to penalise him with gossip for his crime as it happened, the club world could also turn on anyone who continued to bring up the issue after its conclusion.

Two years after Oscar Wilde was publicly tried and convicted under section eleven of the Criminal Law Amendment Act, he was trying to live a quiet life on the continent. After Wilde's release from prison, some could apparently not resist the temptation to continue to talk about the scandal. Wilde actually wrote to chide a man for gossiping about him at the Authors' Club so loudly he imagined it could be heard in Naples. ${ }^{97}$ And most gentlemen would have agreed with Wilde. To continue to talk about such an unpleasant event, after the public trial had already occurred, was just to bring up an inappropriate subject that should be ignored. Wilde was vilified not simply because he transgressed sexual boundaries, which many others also had to varying degrees, but because he let his private sexual life become common gossip. ${ }^{98}$ The fact that his secret became public entailed punishment, but to continue to belabour the point was in bad taste, and opened up questions of one's own gentlemanly status.

With all of these examples of men's gossip, the question of why gossip was such a feminised term becomes increasingly important. One explanation is that, just as a focus on the underclass has precluded the study of elite gossip, so too has the focus on women ignored men as the source of such talk. The exclusive connection between gossip and women in many ways echoes the intense focus on women's private lives at the expense of men's. As historians of 
masculinity explore the social lives of men, we find that many of the previously accepted stereotypes about the late nineteenth-century man prove incorrect. ${ }^{99}$ And yet even historians of masculinity tend to focus on men's public pursuits; one of the largest debates centres on when in the nineteenth century masculinity eschewed a domestic side in favour of hyper masculinity. As Martin Francis points out, one should rather see how men attempted to reconcile these two contradictory impulses. ${ }^{100}$ Preliminary examinations of exclusively male institutions have found that even these embraced domestic comforts and catered to emotional needs. ${ }^{101}$ While Victorian culture preached the dichotomies of men's and women's natures, in reality their habits and values were not always different. Men and women both gossiped, but how they did so, and how it was understood, point to how a gendered society functions.

In conclusion, gossip functioned as a potent way to define the boundaries of clubland, and of elite male society in general. As such, the community displayed and exercised a sense of power in the social sphere. As Michel Foucault noted, society is composed of multiple relations of power that infuse, exemplify and construct the social body. In particular, he sees the production of discourse as the way these power relations manifest themselves. ${ }^{102}$ Thus clubmen, through crafting their stories and forming the rules surrounding their circulation, helped to reify and manifest their social power both over society at large and within their own male society. Verbal gossip and printed society news functioned as a complementary system of knowledge only fully accessible to those in elite male circles. Clubmen created a community of gossip that existed both in their private enclaves and within society at large.

While there were certainly limits to what could be held in check by the clubhouse door, as a rule club secrets were well kept. The fact that gossip is a difficult history to access should not, however, obscure the influence it had in society. The examination of club gossip also highlights the need to re-examine the assumed norms of gendered behaviour. There are certainly numerous cases where one can find women singled out as the sole perpetrators of gossip. And yet these coexist with evidence and information that explicitly contradicts this assertion. Beyond the one-sided vision of prescriptive literature, the world of popular culture reveals a much more nuanced and complicated picture of gendered activities. In the late nineteenth century, it was publicly acknowledged that both men and women discussed the latest rumours, told scandalous tales, repeated half-truths and generally indulged in the pleasurable pastime of gossip.

Notes

The author would like to thank the Footnotes reading group, Andrew Haley, Lori Loeb, Michele Mitchell, Regina Kunzel and the anonymous reviewers for their helpful and insightful comments. 1. C. Stein, 'Yarns in the Club Smoking-Room: A VC', Pall Mall Magazine, 18 October 1894, p. 195.

2. Paul Deslandes examines similar institutions of elite masculine identity, the universities of Oxford and Cambridge, to see how these young men cemented the skills of exclusion. Paul Deslandes, Oxbridge Men: British Masculinity and the Undergraduate Experience 1850-1920 (Bloomington: Indiana University Press, 2005).

3. James C. Scott, Weapons of the Weak: Everyday Forms of Peasant Resistance (New Haven: Yale University Press, 1985), p. 282.

4. Laura Gowing, Domestic Dangers: Women, Words, and Sex in Early Modern London (New York: Oxford University Press, 1999), p. 123.

5. This favourable sense first appeared in 1811. Oxford English Dictionary. 
6. Elizabeth A. Foyster, Manhood in Early Modern England: Honour, Sex, and Marriage, Women and Men in History (Harlow: Longman, 1999), p. 58.

7. Melanie Tebbutt is the only scholar to spend much time in the nineteenth century at all. Her focus, however, is exclusively on women of the working class. Melanie Tebbutt, Women's Talk? A Social History of 'Gossip' in Working-Class Neighbourhoods, 1880-1960 (Aldershot: Scolar Press, 1995).

8. Scott, Weapons of the Weak, pp. 282-3.

9. Bernard Capp, When Gossips Meet: Women, Family, and Neighbourhood in Early Modern England (Oxford: Oxford University Press, 2003), pp. 2, 60, 381.

10. John Beard Haviland, Gossip, Reputation, and Knowledge in Zinacantan (Chicago: University of Chicago Press, 1977), p. 5.

11. Gowing, Domestic Dangers, pp. 121-3.

12. Scott even specifically references the colonial clubs in Burma as a site where British officials could retire from their performance as imperial overlords. James C. Scott, Domination and the Arts of Resistance: Hidden Transcripts (New Haven: Yale University Press, 1990), pp. 10-11, 12.

13. Haviland, Gossip, Reputation, and Knowledge, pp. 3, 6.

14. In Mrinalini Sinha's excellent article on the function of the gentlemen's club in India, she discusses the club's important role in maintaining racial divisions in the colonies, and helping define the boundaries of whiteness. Club life always has the dual purpose of keeping others out and keeping insiders together. Mrinalini Sinha, 'Britishness, Clubbability, and the Colonial Public Sphere: The Genealogy of an Imperial Institution in Colonial India', Journal of British Studies 40 (2001), pp. 489-521.

15. Even before the history of masculinities was prevalent, historians were very interested in the gentlemanly ideal and, with the infusion of gendered history, the scholarship continues. Michael Brander, The Victorian Gentleman (London: Gordon Cremonesi, 1975); Philip Mason, The English Gentleman: The Rise and Fall of an Ideal (London: Andre Deutsch, 1982); David Castronovo,' The English Gentleman: Images and Ideals in Literature and Society (New York: Ungar, 1987); Penny Corfield, 'The Democratic History of the English Gentleman', History Today 42 (1992), pp. 40-47; John Tosh, 'Gentlemanly Politeness and Manly Simplicity in Victorian England', Transactions of the Royal Historical Society 12 (2002), pp. 455-72. 16. Jan B. Gordon, Gossip and Subversion in the Nineteenth-Century Novel: Echo's Economies (New York: St Martin's Press, 1996), pp. 38-9.

17. Peter Clark, British Clubs and Societies, 1580-1800: The Origins of an Associational World (New York: Oxford University Press, 2000); Brian Cowan, 'Mr Spectator and the Coffeehouse Public Sphere', Eighteenth-Century Studies 37 (2004), pp. 345-66.

18. This figure includes gentlemen's clubs in their most embracive sense. Anthony Lejeune, White's: The First Three Hundred Years (London: A \& C Black, 1993), p. 132.

19. 'Club-Cleaning', The World: A Journal for Men and Women 530 (1884), p. 9; 'London in Winter', World 290 (1880), p. 6.

20. Ex-Attache, 'London's Leading Club: Features of English Club Life and the Relative Status of the Clubs ' of the Metropolis', New York Daily Tribune, 19 January 1902, p. 10.

21. Francis Waugh, The Athenaeum Club and its Associations (London: printed for private circulation, 1894), p. 14.

22. 'Clubs', Vanity Fair, 11 March 1882, p. 138.

23. Capp, When Gossips Meet, p. 51. 
24. Oxford English Dictionary.

25. Capp, When Gossips Meet, p. 63.

26. Punch, 21 March 1900, p. 205. Sometimes the critique was less explicit, such as in another cartoon that simply demonstrates a group of women enjoying some gossip. Punch, 24 July 1912, p. 89.

27. 'The Joys of Scandal-Bearing', Punch, 21 March 1896, p. 136.

28. E.g., 'Club Gossip from London: Notes from the Metropolis', New York Times, 19 August 1877, p. 1; 'European Gossip: From Our London Correspondent', New York Times, 5 December 1886, p. 5; 'Gossip from England: London Society and the Drama', New York Times, 9 July 1877, p. 5; 'London Gossip of the Day: Notes on Politics, Society, Books, and the Stage', New York Times, 3 June 1882, p. 5.

29. Unfortunately, determining reliable authorship is almost impossible in the periodical literature. At most, lengthy articles might have pseudonyms or initials, but the majority of shorter works are without even such clues.

30. The published biography of George Alexander Baird reads as an extended gossip column on the gentleman jockey who died at the age of thirty-two. He was a constant source of gossip during his life as a wealthy spendthrift who was heavily involved in both the turf and the boxing circuit. John Malcolm Bulloch, The Last Baird Laird of Auchmedden and Strichen: The Case of Mr Abington (Aberdeen, 1934).

31. Bourke, The History of White's, vol. 2.

32. Brooks's saw only nineteen bets made between 1860 and 1892 , yet by the early twentieth century there were on average half a dozen bets made every week. 'The Betting Book [typed copy] 26 March 1771 - 8 August 1892', ACC/2371/BC/04/073/A; 'The Betting Book [typed copy] 2 December 1906 - 28 February 1909', ACC/2371/BC/04/074, London Metropolitan Archives.

33. E.g, Herbert Henry Asquith, Memories and Reflections, 1852-1927, vol. 1 (London: Cassell, 1928); Sir Charles Biron, Without Prejudice: Impressions of Life and Law (London: Faber and Faber, 1936); Barnaby Brook [pseud.], Mock-Turtle: Being the Memoirs of a Victorian Gentleman (New York: Minton Balch \& Company, 1931); Almeric William Fitzroy, Memoirs (3rd edn, London: Hutchinson, 1925).

34. Hamilton, 'The Diary of Edward Hamilton', vol. 7 (7 April 1884), British Library, ADD.MSS.48636, 16.

35. Hamilton, 'The Diary of Edward Hamilton', vol. 16 (1 December 1886), British Library ADD.MSS.4865, 38.

36. Montstuart E. Grant Duff, Notes from a Diary, vol. 1 (New York: E. P. Dutton, 1905), pp. 21-2, 294.

37. Henry Lucy, The Diary of a Journalist, vol. 2 (London: John Murray, 1920), p. 152.

38. Vanity Fair, 31 January 1891, p. 91.

39. George Leveson-Gower, Years of Content 1858-1886 (London, 1940), p. 171.

40. E.g., in Hamilton's diary, references to women are often coded and personal details are left out.

41. E.g., E. F. Benson's chatty memoir discusses the lives of some women at great length, but it was not published until 1930. E. F. Benson, As We Were: A Victorian Peepshow (1930; repr. Toronto: Penguin Books, 2001). 42. 'Lady Hetty: A Story of To-Day', Vanity Fair, 16 January 1896, p. 47. 
43. Mrs Irwin Smart, 'Which?' Vanity Fair, 23 July 1913, p. 95. In E. F. Benson's story the rumours are more vague at the man's club and, though widespread, are presented as untrue. E. F. Benson, Dodo; a Detail of the Day (2nd edn, New York: D. Appleton, 1894), p. 190.

44. Joseph Hatton, 'London Club-Land', Art Journal, April 1885, p. 100.

45. Un Garc ,on, 'The Social Pilgrimage: Clubs and Clubmen', Vanity Fair, 7 September 1893, p. 153.

46. The OED defines it as 'Having such qualities as fit one to be a member of a club; sociable'. Sociable seems a rather empty add-on, the closest one could get at for what is, in fact, a far more nuanced word.

47. Vanity Fair, 12 November 1887, p. 303.

48. Setting tales in India seems a universally acceptable way to tell outlandish or scandalous tales. One wonders if, in the Indian clubs, London proved the site of the best stories.

49. Benson, As We Were, pp. 86-7.

50. Emeric Hulme Beaman, 'Vain Tale. - No. DXCIII. His Friend's Name', Vanity Fair, 3 April 1902.

51. There is a record of at least one suicide occurring on club premises that was probably the subject of many club wags. In May 1905, Percival Osborn shot himself in the lower billiard room of the Travellers Club. His death was officially ruled a suicide due to temporary insanity. The shame of this act was accentuated by the fact that he killed himself in a relatively public way. The son of the deceased man wrote to the club committee soon after to apologise for his father's act. 17 May 1905, 'Committee Minute Book 18 November 1903 - 18 December 1907', p. 140, Travellers Club Archive.

52. C. Stein, 'Yarns in the Club Smoking-Room: A Death Vacancy', Pall Mall Magazine 3:14 (1894); Stein, 'Yarns in the Club Smoking-Room: A VC'. A series entitled 'Bribery and Corruption: Some Club Yarns' ran for seven consecutive weeks in Vanity Fair in June and July 1910.

53. Black and White had a weekly column in the 1890s entitled 'In the Smoking Room' where a group of men discussed the day's popular topics - amusing news, court cases, ladies' fashions. 54. 'Overheard at the Club', Vanity Fair, 15 February 1906, p. 210.

55. Determining the authorship of such tales is almost impossible. However, clubmen were certainly heavily involved in the periodical press, and it is unlikely they would have allowed any gross misrepresentation of life behind the clubhouse doors.

56. Betraying club secrets would have come under the rubric of 'ungentlemanly' conduct, punishable by expulsion. Every club had a rule, similarly phrased, that worked as a catch-all for any behaviour deemed inappropriate by stating that, if a member 'committed a specified act, or acts, inconsistent with the character of a gentleman', he could be expelled. See e.g., The Rules and Regulations of the East India United Service Club (London: W. Boyle, 1890), p. 19.

57. Roger Fulford, Boodle's 1762-1962: A Short History (London: Eyre \& Spottiswoode, 1962), p. 1.

58. 'Club Manners', World, 2 July 1884, p. 9. This point holds true for the modern historian as well. When I contacted Boodle's Club, I was informed that the club holds virtually no records from the nineteenth century.

59. A motto modelled on one of Horace's epistles hung in the club dining room and read: 'Let no one bear beyond this threshold hence, words uttered here in friendly confidence'. 'Henry Irving at Home', Harper's New Monthly Magazine 64:381 (1882), p. 392.

60. G. M. Wrong, The Savile Club, 1868 to 1923 (London, 1923), p. 24. 
61. This very closely mirrors the phenomenon among early modern English women, eighteenthcentury salonnieres and universally among dominant elites. Capp, `When Gossips Meet, p. 381; Benedetta Craveri, The Age of Conversation (New York: New York Review Books, 2005), p. 338; Scott, Domination and the Arts of Resistance, p. 12.

62. Stanley Naylor, Gaiety and George Grossmith: Random Reflections on the Serious Business of Enjoyment (London: Stanley Paul, 1913), p. 179.

63. This is an uneven area of British historiography, taken for granted but rarely explored. See, though, Deslandes, Oxbridge Men; David Gilmour, The Ruling Caste: Imperial Lives in the Victorian Raj (New York: Farrar, Straus and Giroux, 2005); Barbara Rogers, Men Only: An Investigation into Men's Organisations (London: Pandora, 1988); John Scott, The Upper Classes: Property and Privilege in Britain (London: Macmillan, 1982), pp. 177-8; John

Raymond de Symons, Tom Brown's Universe: The Development of the Victorian Public School (London: Millington, 1977).

64. 'Club Blabs', Smart Society, 14 December 1892, p. 17.

65. See e.g., Belgravia (1873), Clubland (1910), Illustrated London News (1880s and 1890s), New York Times (1890), New York Tribune (1900,1902), Pall Mall Gazette (1912), Smart Society (1893), Society Herald (1888), Times (1880), Vanity Fair (1910); even Queen detailed ladies' clubland (1893).

66. Joseph Hatton, 'London Club-Land II', Art Journal, May 1885, p. 130.

67. Percy Fitzgerald to Garrick Club sub-committee, 4 October 1904, Box 2, 1900-49, Garrick Club Archive (GCA), London. Fitzgerald's book proves his claim, as it focuses on the early history of the club, its picture collection and the early days of the London theatre. Percy Fitzgerald, The Garrick Club (London: Elliot Stock, 1904).

68. Percy Fitzgerald to Garrick Club sub-committee, 18 March 1905, Box 2, 1900-49, GCA. 69. Lord Edmund Talbot to Arthur Lee, 6 September 1914, 34/5/17, Bonar Law Papers, House of Lords Record Office, London.

70. To be expelled from a club was a serious punishment and was treated as a sort of social ostracism. It would be difficult for a man to recover from such exclusion.

71. Unfortunately, due to the destruction of the Carlton clubhouse during the Second World War, there are no existing minute books from this period to verify if this case ever came before the club committee.

72. Michael Curtin, Propriety and Position: A Study of Victorian Manners (New York: Garland, 1987), p. 148.

73. Two of the most famous examples of this were Robert Smythe Hichens, The Green Carnation (London: William Heinemann, 1894), a scandalous novel based on Oscar Wilde and Lord Alfred Douglas, and the more popular Dodo by E. F. Benson, a novel about a heroine modelled on Margot Asquith. See also Trevor Fisher, Oscar and Bosie: A Fatal Passion (Stroud: Sutton, 2002), p. 76.

74. Mary Douglas, 'Jokes', in Chandra Mukeiji and Michael Schudson (eds), Rethinking Popular Culture: Contemporary Perspectives in Cultural Studies (Berkeley: University of California Press, 1991), pp. 291-310, here p. 293.

75. Richard Alexander Hough, The Ace of Clubs: A History of the Garrick (London: Andre Deutsch, 1986), 'p. 117.

76. William Thackeray to Edmund Yates, 13 June 1858, Box 1, 1831-99, GCA.

77. A further layer to the story is that Yates's article was published on the same day that Dickens publicly announced his separation from his wife. The literary rivalry, and the fact that Dickens 
believed Thackeray had been spreading rumours about his separation in the Garrick make it difficult to believe the timing was mere coincidence. P. D. Edwards, Dickens's 'Young Men': George Augustus Sala, Edmund Yates and the World of Victorian Journalism (Aldershot: Ashgate, 1997), p. 62.

78. Alexander Doland to Edmund Yates, c.1858, Box 1, 1831-99, GCA.

79. According to his lawyer, the committee had no power to expel, as he had not transgressed any specific club rule. Mssrs Farrer \& Co. to Alexander Doland, 3 August 1858, Box 1, 183199, GCA.

80. More than twenty years after the fact he again published the correspondence with notes, proving the event was still in the public consciousness in the 1880s. While he claimed no bitterness as to his expulsion, he still believed in the injustice of the act. Edmund Yates, Mr. Thackeray, Mr Yates, and the Garrick Club: The Correspondence and Facts (London: Taylor \& Greening, 1859); Edmund Yates, 'An Old Club Scandal', c. January 1880, Box 1, 1831-99, GCA.

81. Anthony Lejeune, The Gentlemen's Clubs of London (London: Macdonald and Jane's, 1979), pp. 34, 127.

82. Gary Weber, 'Henry Labouchere, Truth and the New Journalism of Late Victorian Britain', Victorian Periodicals Review 26 (1993), pp. 36-9.

83. Mark Hampton, Visions of the Press in Britain, 1850-1950 (Champaign: University of Illinois Press, 2004), p. 12.

84. Margaret Beetham, A Magazine of Her Own? Domesticity and Desire in the Women's Magazine, 1800- 1914 (New York: Routledge, 1996).

85. 'A Phase of Humbug', Vanity Fair, 3 December 1881, p. 314.

86. 'Society Journalism', World, 21 March 1883, p. 8.

87. My forthcoming work on club life in general deals more explicitly about club membership and the politics of blackballing.

88. 'Club Life in London: The Leading Clubs of the City', New York Times, 20 March 1877, p. 1.

89. This could be a way to discredit a rival. For example, the editor of Vanity Fair attacked a correspondent of To-Day, a short-lived rival paper, not on the basis of the veracity of the man's information, but for the propriety of his disclosure. Vanity Fair, 29 December 1898, pp. 448-9. 90. Isabella, 'A Letter from an American Lady', World 321 (1880), p. 18.

91. A Member of the St James's Club, 'The St James's Club', Vanity Fair, 11 December 1881, p. 335.

92. Vanity Fair, 11 December 1881, p. 335. When the Times reported on proposed rule changes at the Reform Club, it similarly excused itself by saying that not only was the issue already public knowledge, but that the changes were publicly relevant. Times, 19 May 1882, p. 9.

93. Vanity Fair, 11 August 1904, p. 165.

94. Michael Havers, Edward Grayson and Peter Shankland, The Royal Baccarat Scandal (London: William Kimber, 1977), p. 60.

95. Havers, Grayson and Shankland, Royal Baccarat Scandal, p. 248.

96. Fisher, Oscar and Bosie, p. 109.

97. Oscar Wilde to R. H. Sherard, 16 October 1897, in Rupert Hart-Davis and Merlin Holland (eds), The Complete Letters of Oscar Wilde (New York: Henry Holt, 2000), p. 963. 
98. That Lord Alfred Douglas remained an acceptable member of the elite owes much to his name having been kept out the papers. His behaviour was an open secret, but he was never put on trial. The fact that Douglas was from an aristocratic family also helped to some degree.

99. For counters to a more aggressive model of late nineteenth-century manhood, see e.g., James

Eli Adams, Dandies and Desert Saints: Styles of Victorian Masculinity (Ithaca: Cornell University Press, 1995); Gail Bederman, Manliness and Civilization: A Cultural History of Gender \& Race in United States, 1880- 1917 (Chicago: University of Chicago Press, 1995); John Tosh, A Man's Place: Masculinity and the Middle-Class Home in Victorian England (New Haven: Yale University Press, 1999).

100. Martin Francis, 'The Domestication of the Male? Recent Research on Nineteenth- and Twentieth-Century British Masculinity', Historical Journal 45 (2002), pp. 637-52, here p. 643. 101. Howard Chudacoff, The Age of the Bachelor: Creating an American Subculture (Princeton: Princeton University Press, 1999); Martin Francis, 'A Flight from Commitment? Domesticity, Adventure and the Masculine Imaginary in Britain after the Second World War', Gender \& History 19 (2007), pp. 163- 85; Stephen Heathorn, 'How Stiff Were their Upper Lips? Research on Late-Victorian and Edwardian Masculinity', History Compass 2 (2004), pp. 1-7; Amy MilneSmith, 'A Flight to Domesticity? Making a Home in the Gentlemen's Clubs of London, 18801914', Journal of British Studies 45 (2006), pp. 796-818.

102. Michel Foucault, 'Two Lectures', in Colin Gordon (ed.), Power/Knowledge: Selected Interviews and Other Writings, 1972-1977 (New York: Pantheon, 1980), pp. 78-108. 